\title{
Significance of Temperature to Larval Survival and Length of Development in Balanus eburneus (Crustacea: Cirripedia)***
}

\author{
Rudolf S. Scheltema and Isabelle P. Williams \\ Woods Hole Oceanographic Institution, Woods Hole, Massachusetts 02543, USA
}

\begin{abstract}
Mortality and length of development of Balanus eburneus nauplii is modified in laboratory culture by both temperature and concentration of unicellular algal food. At 20 and $25^{\circ} \mathrm{C}$ mean larval survival was $63.5 \%$ and $66.0 \%$, respectively, at an algal concentration of $1 \times 10^{5} \mathrm{cells} \mathrm{ml}^{-1}$. When the algal concentration was doubled to $2 \times 10^{5}$ cells ml ${ }^{-1}$ mean survival increased significantly to 92.5 and $96.5 \%$ at 20 and $25^{\circ} \mathrm{C}$, respectively ( $p=0.002$ at both temperatures). At $30^{\circ} \mathrm{C}$ the difference in mortality related to algal food concentration disappeared and mean survival was above $90 \%$ at both concentrations. Over the interval of 20 to $30^{\circ} \mathrm{C}$, time to complete development to the cyprid stage decreased from a median of 7.6 to $3.9 \mathrm{~d}$ at $2 \times 10^{5}$ cells ml-1 and from 10.8 to $3.9 \mathrm{~d}$ at the lower food level of $1 \times 10^{5} \mathrm{cells} \mathrm{ml} \mathrm{m}^{-1}$. At $30^{\circ} \mathrm{C}$ there was no difference between the 2 food concentrations in the median time to reach the cyprid stage. The hypothesis is proposed that increased algal cell concentration at 20 and $25^{\circ} \mathrm{C}$ compensates for lower feeding efficiency and consequently results in better survival. To account for the similarity in development time at $30^{\circ} \mathrm{C}$ at either food concentration, it is proposed that maximum possible food intake at $30^{\circ} \mathrm{C}$ is already attained at $1 \times 10^{5} \mathrm{cells} \mathrm{ml}^{-1}$ and that therefore increase in the number of algal cells will not further affect development rate to the cyprid stage. Experiments on feeding efficiency of $B$. eburneus nauplii in relation to temperature will be needed to test this hypothesis.
\end{abstract}

\section{INTRODUCTION}

The research described here undertakes to show by laboratory experiments how differences in seawater temperature may affect mortality and length of planktonic development of the 6 nauplius larvae belonging to the common estuarine barnacle Balanus eburneus Gould, a species indigenous to the region between Massachusetts (USA) and northeastern South America and subsequently introduced into many other parts of the world including the Mediterranean Sea, Black Sea and various areas of the Pacific Ocean (Henry and McLaughlin, 1975, p. 60).

Even though temperature is known to be a factor regulating mortality and length of planktonic larval life in a variety of marine invertebrates, only few previously published studies consider its role through all 6 naupliar stages. Hirano (1962) in a laboratory experiment showed for Balanus amphitrite hawaiiensis the relationship between water temperature and length of development to the cyprid stage. Tighe-Ford et al. (1970) considered the effect of temperature on mortality and the time required for complete development through the 6 naupliar stages of Elminius modestus, but presented only few quantitative data. The remaining published accounts dealing with the role of temperature on the development of nauplii are restricted to experiments using either the embryos and first nauplii readily obtained from breeding adults or alternatively late larval stages taken from the plankton (e.g. Barnes and Barnes, 1958; Crisp and Ritz, 1967). In such studies the intermediate naupliar stages were not considered.

\footnotetext{
- This paper is dedicated to the memory of Dr Harold Barnes who made so many important contributions to the ecology and physiology of Cirripedia

- Contribution Number 4950 from the Woods Hole Oceanographic Institution
} 


\section{METHODS}

The larvae of Balanus eburneus were first reared and described by Costlow and Bookhout (1957). Subsequently they have been grown with varying success in a number of other laboratories (Freiberger and Cologer, 1966; Landau and d'Agostino, 1977, 1978).

The earliest stages of barnacle development occur within the ovigerous lamellae of the parent, and gravid adults collected during the breeding season readily release first stage nauplii when held in $4-1$ jars. The short first nauplius stage does not feed; the remaining 5 planktonic nauplii are phytoplanktotrophic and develop when fed upon a diet of unicellular algae. The final free-swimming cyprid is a non-feeding larva which settles and subsequently attaches onto a hard surface.

Several unicellular algae grown in single-species cultures were initially tried as food for the nauplii of Balanus eburneus. The algal species tried included Thalassiosira pseudonana (W.H.O.I.", Clone $3 \mathrm{H}=$ Cyclotella nana used by Freiberger and Cologer, 1966), Skeletonema costatum, Isochrysis galbana, Pavlova lutheri ( = Monochrysis lutherl), Dunaliella tertiolecta and Platymonas sp. (W.H.O.I., Clone 1). Differences were found in the survival and growth of nauplii with each species offered. For example, in an experiment using Dunaliella tertiolecta at $25^{\circ} \mathrm{C}$ at either $1 \times 10^{5}$ or $2 \times 10^{5}$ cells $\mathrm{ml}^{-1}$, survival to the cyprid stage was only 8 to $10 \%$, whereas $T$. pseudonana at a similar temperature and concentration gave a survival of 36 and $80 \%$, respectively, even though cells of $D$. tertiolecta have on average twice the volume of T. pseudonana (i.e. $400 \mu \mathrm{m}^{3}$ and $203 \mu^{3}$, respectively).

Combinations of more than one algal species consistently resulted in greater survival and faster development of nauplii than when any single species was used as food. Combinations of Thalassiosira pseudonana at a ratio of 1:1. with either Dunaliella tertiolecta, Pavlova lutheri or Platymonas sp. gave uniformly high survival approaching $90 \%$ or better. Cultures of nauplii offered 3 species of algae, e.g. $P$. lutheri, Platymonas sp. and $T$. pseudonana at ratios of $1: 1: 1$ or $1: 1: 2$, respectively, and a total combined concentration of $2 \times 10^{5}$ cells $\mathrm{ml}^{-1}$ also showed very high survival. Enhancement of growth and survival when more than one algal species is used as food also has been shown for bivalve veligers (Davis and Guillard, 1958 ) and a number of other phytoplanktotrophic invertebrate larvae. However, it has not been our purpose here to define the precise relative food value of the different algal species or combination of algal

\footnotetext{
- Woods Hole Oceanographic Institution (Massachusetts,
} USA) species (vide Moyse, 1963; Lang, 1977), but rather to find a source of food that will sustain the five successive feeding naupliar instars to the cyprid stage.

Initially wide variations in survival and growth of larvae resulted from one culture to the next, even when the same species of alga were used as food. Apparently such variations were not related to differences in the condition or 'quality' of the alga used (e.g. age of the algal culture or growth medium used) but rather to differences between different broods of larvae. Progeny from different parents show larger variations in survival than siblings from the same parent even when all cultures are grown simultaneously under identical conditions. As much as a $35 \%$ difference in survival occurred between larvae arising from different parents from the same population.

To minimize the variables inherent in our experiments we established the following prerequisites: (1) Larvae were always siblings from the same parents (some may be 'half' siblings since it is not known whether or not the parents were promiscuous); (2) experiments at all temperatures tested were conducted concurrently using algal food from the same cultures; (3) algal food organisms with wide spectra of temperature tolerance were selected since we wished to know the direct effect of temperature upon the larvae themselves and not the indirect effects resulting from the effect of temperature upon the algal food (Scheltema 1967, p. 262)

The experimental procedure was as follows. Nauplii were grown in $100 \mathrm{mI}$ of $25 \mathrm{ppt}$ seawater in covered dishes $9 \mathrm{~cm}$ in diameter and $5 \mathrm{~cm}$ high and fed from unialgal cultures of Pavlova lutheri, Platymonas sp. and Thalassiosira pseudonana at ratios of $1: 1: 1$ and $1: 1: 2$ and at total concentrations of $1 \times 10^{5}$ and $2 \times 10^{5}$ cells $\mathrm{ml}^{-1}$. The larvae were obtained from adult Balanus eburneus found in Eel Pond at Woods Hole and in nearby Green Pond in the town of Falmouth, Massachusetts, USA. Replicate cultures of 50 nauplii obtained from a single gravid $B$. eburneus were grown in cabinets at 20,25 and $30^{\circ} \mathrm{C}$. Hence, siblings (or half siblings) fed from the same algal cultures were compared in replicate at 3 different temperatures spanning the range within which nauplii larvae normally occur during development in the region of Cape Cod (Fish. 1925). Larvae were examined daily to determine survival. The surviving nauplii were transferred to clean culture dishes with fresh seawater and algae. Cultures were maintained at a 12 h light-dark cycle.

\section{RESULTS}

\section{Survival}

The effect of temperature on the successful completion of development to the cyprid stage is summarized 
in Table 1 and shown graphically in Fig. 1 where the percent survival of sibling (or half sibling) nauplii is given for 3 different temperatures, 20,25 and $30^{\circ} \mathrm{C}$ and at 2 concentrations of algal food, $1 \times 10^{5}$ and $2 \times 10^{5}$ cells $\mathrm{ml}^{-1}$. At the greater of the 2 algal concentrations (i.e. $2 \times 10^{5}$ cells $\mathrm{ml}^{-1}$ ) there were no significant differences in percent mortality among the 3 different temperatures $(\mathrm{p}>0.50)$; survival was uniformly high, ranging from 88 to $100 \%$. At the lower algal concentration there was, however, a significant difference in survival correlated with temperature. At $25^{\circ} \mathrm{C}$ a mean survival of $66.0 \%$ (range 60 to $72 \%$ ) was significantly less than $89.5 \%$ (range 84 to $94 \%$ ) found at $30^{\circ} \mathrm{C}$ $(\mathrm{p}=0.01)$. A comparison between cultures grown at the higher and lower algal concentrations show significant differences at 20 and $25^{\circ} \mathrm{C}(\mathrm{p}<0.002$ in both instances). When reared at $1 \times 10^{5}$ cells $\mathrm{ml}^{-1}$, survivorship of larvae in the experiments averaged $29 \%$ less at $20^{\circ} \mathrm{C}$ (range 22 to $34 \%$ ) and $30.5 \%$ less at $25^{\circ} \mathrm{C}$ (range

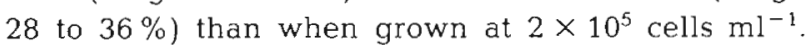
Such a difference disappeared at $30^{\circ} \mathrm{C}$ at which temperature mortality was never greater than $16 \%$ at either algal concentration.

Nauplii did not consistently reach the cyprid stage at algal concentrations of less than $1 \times 10^{5}$ cells ml ${ }^{-1}$; at a food concentration of $1 \times 10^{4}$, development was rarely completed. This result is in agreement with experiments on other species of barnacle nauplii larvae by Hirano (1962) who used Skeletonema costatum at $10^{4}$ to $10^{5}$ cells $\mathrm{ml}^{-1}$; by Moyse (1963) who utilized Phaeodactylum tricornutum at $5 \times 10^{4}$ to $10^{6}$ cells $\mathrm{ml}^{-1}$; by Freiberger and Cologer (1966) who used 1 to $2 \times 10^{5}$ cells $\mathrm{ml}^{-1}$ of Cyclotella nana ( = Thalassiosira pseudonana); and finally by Tighe-Ford et al. (1970) who used Skeletonema costatum at 1 to $2 \times 10^{6}$ cells $\mathrm{ml}^{-1}$. Only Hirano, who employed a running water system, was able to obtain some cyprids at food concentrations as low as $1 \times 10^{4}$ cells $\mathrm{ml}^{-1}$

\section{Length of Development}

The median time interval required for $50 \%$ of the nauplii to reach the cyprid stage was computed to the nearest $0.1 \mathrm{~d}$ by linear interpolation from data in Table 2. Results of these computations are compiled in Table 3 and show that at $2 \times 10^{5}$ cells $\mathrm{ml}^{-1}$ there is a statistically significant difference in the median time required for development to the cyprid between 20 and $25^{\circ} \mathrm{C}(\mathrm{p} \cong 0.001)$ but not between 25 and $30^{\circ} \mathrm{C}$ $(\mathrm{p}>0.10)$

At the lower algal concentration of $1 \times 10^{5} \mathrm{cells} \mathrm{ml}^{-1}$ there is a statistically significant difference in median time required for development between each temperature interval ( $\mathrm{p} \cong 0.05$ between 20 and $25^{\circ} \mathrm{C} ; \mathrm{p} \cong 0.001$ between 25 and $30^{\circ} \mathrm{C}$ ).

When comparing the effect of temperature between the 2 algal concentrations used there is a significant difference in median time required for development to the cyprid at both 20 and $25^{\circ} \mathrm{C}(\mathrm{p} \equiv 0.01$ and 0.001 , respectively) but not at $30^{\circ} \mathrm{C}$. These relationships can be seen in Fig. 2 which shows the difference in response of the nauplii larvae to increasing temperature in relation to the concentration of food present; a shorter time interval was required at both 20 and $25^{\circ} \mathrm{C}$ to reach the cyprid stage at $2 \times 10^{5}$ than at $1 \times 10^{5}$ cells $\mathrm{ml}^{-1}$. At $30^{\circ}$ there is no significant difference in median time to complete development between the two concentrations.

\section{DISCUSSION}

The temperature range within which the development of Balanus eburneus nauplii normally occurs in

Table 1. Balanus eburneus. Percent survival to cyprid stage by nauplii at 3 different temperatures using 2 concentrations of mixed unicellular algea, Pavlova lutheri, Platymonas sp. and Thalassiosira pseudonana at ratios of $1: 1: 1$ and $1: 1: 2$ as a source of food"

\begin{tabular}{|c|c|c|c|c|c|c|}
\hline \multirow[t]{2}{*}{ Algal species ratio " } & \multicolumn{3}{|c|}{$2 \times 10^{5}$ cells $\mathrm{ml}^{-1}$} & \multicolumn{3}{|c|}{$1 \times 10^{5}$ cells $\mathrm{ml}^{-1}$} \\
\hline & $20^{\circ} \mathrm{C}$ & $25^{\circ} \mathrm{C}$ & $30^{\circ} \mathrm{C}$ & $20^{\circ} \mathrm{C}$ & $25^{\circ} \mathrm{C}$ & $30^{\circ} \mathrm{C}$ \\
\hline $1: 1: 1$ & 88 & 96 & 98 & 58 & 60 & 92 \\
\hline $1: 1: 1$ & 92 & 90 & 94 & 62 & 62 & 84 \\
\hline $1: 1: 2$ & 96 & 100 & 98 & 62 & 72 & 88 \\
\hline $1: 1: 2$ & 94 & 100 & 98 & 72 & 70 & 94 \\
\hline Mean & 92.5 & 96.5 & 97.0 & 63.5 & 66.0 & 89.5 \\
\hline$s$ & 3.4 & 4.7 & 2.0 & 6.0 & 5.9 & 4.4 \\
\hline$s / \sqrt{n-1}$ & 2.0 & 2.7 & 1.2 & 3.4 & 3.4 & 2.6 \\
\hline \multicolumn{7}{|c|}{$\begin{array}{l}\text { - Survival data derived from Table } 2 \\
\text { There is no statistically significant difference between survival values of the } 2 \text { different 'algal species ratios'. } \\
\text { Consequently, these ratios have been ignored in computing the mean values for survival }\end{array}$} \\
\hline
\end{tabular}




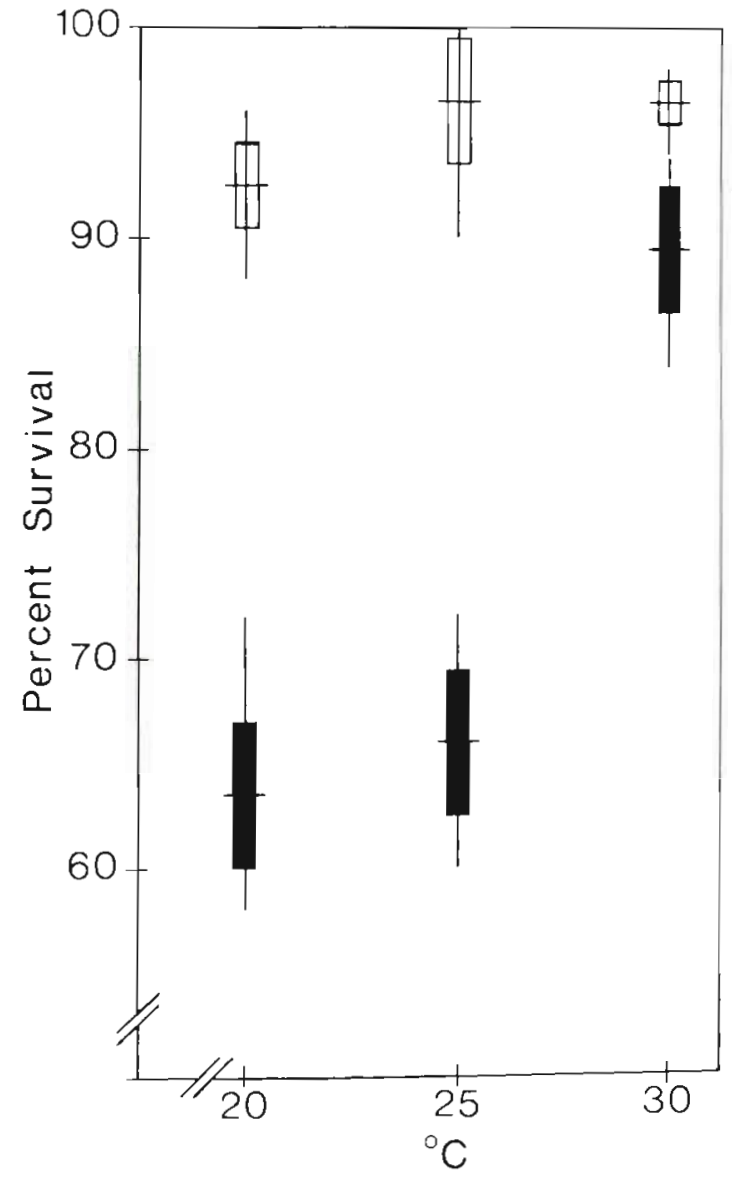

Fig. 1. Balanus eburneus. Percentage survival of nauplii larvae to the cyprid stage at 3 different temperatures. Vertical bars: results of 4 experiments with 50 larvae each. Filled bars: cultures of nauplii grown at an algal concentration of $1 \times 10^{5}$ cells $\mathrm{ml}^{-1}$; open bars, at an algal concentration of $2 \times 10^{5}$ cells $\mathrm{ml}^{-1}$. Mean survivals indicated by short horizontal lines; length of bars shows 2 standard errors on each side of mean survival. Long vertical lines through the bars are extreme survival values. Data derived from Table 2 and compiled in Table 1

natural populations at Woods Hole, Massachusetts, USA lies between 20 and $30^{\circ} \mathrm{C}$. Laboratory experiments show that an increase from 20 to $25^{\circ}$ does not significantly enhance larval survival; however, doubling the food concentration from $1 \times 10^{5}$ to $2 \times 10^{5}$ cells $\mathrm{ml}^{-1}$ at either 20 or $25^{\circ} \mathrm{C}$ increases mean survival by $30 \%$. Further increase in temperature from 25 to $30^{\circ}$ again does not significantly affect larval survival at the higher cell concentration tested $\left(2 \times 10^{5} \mathrm{ml}^{-1}\right)$, but increases survival by more than $20 \%$ at the lower cell concentration of $1 \times 10^{5} \mathrm{mI}^{-1}(\mathrm{p}=0.001)$. At $30^{\circ} \mathrm{C}$ there is no statistically significant difference in survival of nauplii between the two food concentrations tested (Table 1, Fig. 1).

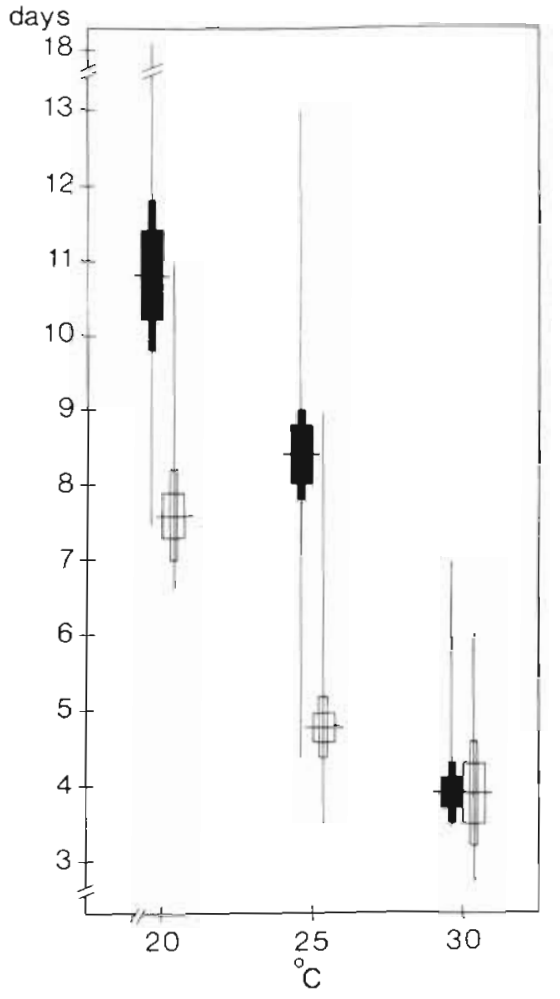

Fig. 2. Balanus eburneus. Mean of the median number of days required by nauplii to reach the cyprid stage at 3 different temperatures. Vertical bars: 4 experiments with 50 larvae each. Filled bars: cultures of nauplii grown at an algal concentration of $1 \times 10^{5} \mathrm{cells} \mathrm{ml}^{-1}$; open bars, at an algal concentration of $2 \times 10^{5}$ cells $\mathrm{ml}^{-1}$. Means of the median values for the 4 experiments indicated by short horizontal lines; one standard error and one standard deviation are shown on each side of the mean median value by the wide and narrow portions of the vertical bar, respectively. Vertical line through the bar shows shortest and longest time required to reach cyprid stages in all experiments represented by the bar (i.e. not the extremes of the median values). Data derived from Tables 2 and 3

Over the interval from 20 to $30^{\circ} \mathrm{C}$, the time to complete development decreased $49 \%$ at $2 \times 10^{5}$ cells $\mathrm{ml}^{-1}$, and $64 \%$ at the lower food level of $1 \times 10^{5}$ cells $\mathrm{ml}^{-1}$. A significant part of the decrease in time required to the cyprid stage at the higher algal concentration occurred between 20 and $25^{\circ} \mathrm{C}$. In contrast, at the lower food concentration the decrease was more uniform over the temperature interval between 20 and $30^{\circ} \mathrm{C}$ (Table 3, Fig. 2).

Some changes in survival and rate of development of nauplii that are related to temperature appear to be paradoxical. For example, why should larvae survive significantly better at 30 than at $25^{\circ} \mathrm{C}$ when grown at low cell levels of $1 \times 10^{5} \mathrm{ml}^{-1}$, whereas the same 
Table 2. Balanus eburneus. Number of nauplius larvae attaining the cyprid stage in cultures of 50 individuals as recorded at 1 -d intervals from the time of their release; larvae grown at 3 different temperatures using 2 concentrations of mixed unicellular algae Pavlova lutheri. Platymonas sp. and Thalassiosira pseudonana as a source of food

\begin{tabular}{|c|c|c|c|c|c|c|c|c|c|c|c|c|c|}
\hline \multicolumn{7}{|c|}{ Algae at $2 \times 10^{5}$ cells $\mathrm{ml}^{-1}$; ratio $1: 1: 1$} & \multicolumn{7}{|c|}{ Algae at $2 \times 10^{5}$ cells $\mathrm{ml}^{-1}$; ratio $1: 1: 2$} \\
\hline \multirow[t]{2}{*}{$\begin{array}{c}\text { Days since } \\
\text { release }\end{array}$} & \multicolumn{2}{|c|}{$\begin{array}{c}20^{\circ} \mathrm{C} \\
\text { Replicate }\end{array}$} & \multicolumn{2}{|c|}{$\begin{array}{c}25^{\circ} \mathrm{C} \\
\text { Replicate }\end{array}$} & \multicolumn{2}{|c|}{$\begin{array}{c}30^{\circ} \mathrm{C} \\
\text { Replicate }\end{array}$} & \multirow[t]{2}{*}{$\begin{array}{c}\text { Days since } \\
\text { release }\end{array}$} & \multicolumn{2}{|c|}{$\begin{array}{c}20^{\circ} \mathrm{C} \\
\text { Replicate }\end{array}$} & \multicolumn{2}{|c|}{$\begin{array}{c}25^{\circ} \mathrm{C} \\
\text { Replicate }\end{array}$} & \multicolumn{2}{|c|}{$\begin{array}{c}30^{\circ} \mathrm{C} \\
\text { Replicate }\end{array}$} \\
\hline & A & $\mathrm{B}$ & A & B & A & B & & $\mathrm{A}$ & B & A & B & A & $B$ \\
\hline 1 & - & - & - & - & - & - & 1 & - & - & - & - & - & - \\
\hline 2 & - & - & - & - & - & - & 2 & - & - & - & - & - & - \\
\hline 3 & - & - & - & - & - & - & 3 & - & - & - & - & 6 & 16 \\
\hline 4 & - & - & - & - & - & 4 & 4 & - & - & 7 & 11 & 44 & 33 \\
\hline 5 & - & - & 23 & 19 & 47 & 44 & 5 & - & - & 37 & 32 & - & - \\
\hline 6 & - & - & 17 & 18 & 1 & - & 6 & - & - & 4 & 6 & - & - \\
\hline 7 & 4 & 1 & 7 & 7 & - & - & 7 & 8 & 31 & 2 & 1 & - & - \\
\hline 8 & 18 & 24 & 1 & - & - & - & 8 & 30 & 12 & - & - & - & - \\
\hline 9 & 13 & 9 & - & 1 & - & - & 9 & 7 & 4 & - & - & - & - \\
\hline 10 & 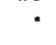 & $\cdot$ & - & - & - & - & 10 & . & - & - & - & - & - \\
\hline 11 & 9 & 10 & - & - & - & - & 11 & 3 & - & - & - & - & - \\
\hline 12 & - & - & - & - & - & - & 12 & - & - & - & & - & - \\
\hline 13 & - & 2 & - & - & - & - & 13 & - & - & - & - & - & - \\
\hline $\begin{array}{l}\text { Total to } \\
\text { cyprid }\end{array}$ & 44 & 46 & 48 & 45 & 48 & 48 & $\begin{array}{l}\text { Total to } \\
\text { cyprid }\end{array}$ & 48 & 47 & 50 & 50 & 50 & 49 \\
\hline \multicolumn{7}{|c|}{ Algae at $1 \times 10^{5}$ cells $\mathrm{ml}^{-1}$; ratio $1: 1: 1$} & \multicolumn{7}{|c|}{ Algae at $1 \times 10^{5}$ cells $\mathrm{ml}^{-1} ;$ ratio $1: 1: 2$} \\
\hline \multirow{2}{*}{$\begin{array}{l}\text { Days since } \\
\text { release }\end{array}$} & \multicolumn{2}{|c|}{$\begin{array}{c}20^{\circ} \mathrm{C} \\
\text { Replicate }\end{array}$} & \multicolumn{2}{|c|}{$\begin{array}{c}25^{\circ} \mathrm{C} \\
\text { Replicate }\end{array}$} & \multicolumn{2}{|c|}{$\begin{array}{c}30^{\circ} \mathrm{C} \\
\text { Replicate }\end{array}$} & \multirow{2}{*}{$\begin{array}{c}\text { Days since } \\
\text { release }\end{array}$} & \multicolumn{2}{|c|}{$\begin{array}{c}20^{\circ} \mathrm{C} \\
\text { Replicate }\end{array}$} & \multicolumn{2}{|c|}{$\begin{array}{c}25^{\circ} \mathrm{C} \\
\text { Replicate }\end{array}$} & \multicolumn{2}{|c|}{$\begin{array}{l}30^{\circ} \mathrm{C} \\
\text { Replicate }\end{array}$} \\
\hline & A & $\mathrm{B}$ & A & B & A & B & & A & $\mathrm{B}$ & A & B & A & B \\
\hline 1 & - & - & - & - & - & - & 1 & - & - & - & - & - & - \\
\hline 2 & - & - & - & - & - & - & 2 & - & - & - & - & - & - \\
\hline 3 & - & - & - & - & - & - & 3 & - & - & - & - & - & - \\
\hline 4 & - & -- & - & - & 20 & 17 & 4 & - & - & - & - & 41 & 45 \\
\hline 5 & - & - & - & - & 18 & 21 & 5 & - & - & 1 & 1 & 2 & 2 \\
\hline 6 & - & - & 1 & 4 & 6 & 4 & 6 & - & - & 2 & 2 & 1 & - \\
\hline 7 & - & - & 4 & 5 & 2 & - & 7 & - & - & 7 & 5 & - & - \\
\hline 8 & - & - & 4 & 5 & - & - & 8 & 3 & - & 10 & 8 & - & - \\
\hline 9 & 3 & - & 4 & 4 & - & - & 9 & 6 & 6 & 9 & 6 & - & - \\
\hline 10 & $\cdot$ & $\cdot$ & $\cdot$ & $\cdot$ & - & - & 10 & $\cdot$ & $\cdot$ & $\cdot$ & $\cdot$ & - & - \\
\hline 11 & 9 & 9 & 16 & 9 & - & - & 11 & 15 & 23 & 7 & 12 & - & - \\
\hline 12 & $\cdot$ & $\cdot$ & 1 & 4 & - & - & 12 & 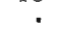 & . & - & - & - & - \\
\hline 13 & 14 & 14 & - & - & - & - & 13 & 7 & 7 & - & 1 & - & - \\
\hline 14 & - & . & - & - & - & - & 14 & - & - & - & - & - & - \\
\hline 15 & 1 & 7 & - & - & - & - & 15 & - & - & - & - & - & - \\
\hline 16 & - & - & - & - & - & - & 16 & - & - & - & - & - & - \\
\hline 17 & - & - & - & - & - & - & 17 & - & - & - & - & - & - \\
\hline 18 & - & 1 & - & - & - & - & 18 & - & - & - & - & - & - \\
\hline $\begin{array}{l}\text { Total to } \\
\text { cyprid }\end{array}$ & 27 & 31 & 30 & 31 & 46 & 42 & $\begin{array}{l}\text { Total to } \\
\text { cyprid }\end{array}$ & 31 & 36 & 36 & 35 & 44 & 47 \\
\hline
\end{tabular}

temperature increase has no apparent effect on mortality of larvae at high algal concentrations? Why are there no differences in the survival or rate of development at $30^{\circ} \mathrm{C}$ regardless of the concentration of algal cells?

It is difficult to imagine how the availability of food alone could account for decreased survival of the lar- vae in any of the experiments. Even the lowest concentration of unicellular algae used in the laboratory experiments exceeded that available to most natural populations of barnacle larvae. For instance, the total mean standing crop of phytoplankton in lower Vineyard Sound, Massachusetts has been measured at $2.3 \times 10^{-1}$ cells $\mathrm{ml}^{-1}$ and only in certain small New 
Table 3. Balanus eburneus. Median number of days required to reach the cyprid stage by nauplii at 3 different temperatures using 2 concentrations of mixed unicellular algae, Pavlova lutheri, Platymonas sp. and Thalassiosira pseudonana at ratios of $1: 1: 1$ and $1: 1: 2$ as a source of food"

\begin{tabular}{|c|c|c|c|c|c|c|c|}
\hline & \multirow[t]{2}{*}{ Algal species ratio * } & \multicolumn{3}{|c|}{$2 \times 10^{5}$ cells $\mathrm{ml}^{-1}$} & \multicolumn{3}{|c|}{$1 \times 10^{5}$ cells ml-1 } \\
\hline & & $20^{\circ} \mathrm{C}$ & $25^{\circ} \mathrm{C}$ & $30^{\circ} \mathrm{C}$ & $20^{\circ} \mathrm{C}$ & $25^{\circ} \mathrm{C}$ & $30^{\circ} \mathrm{C}$ \\
\hline & $1 ; 1: 1$ & 8.0 & 5.0 & 4.5 & 11.2 & 9.3 & 4.2 \\
\hline & $1: 1: 1$ & 7.9 & 5.2 & 4.5 & 11.9 & 8.4 & 4.2 \\
\hline & $1: 1: 2$ & 7.5 & 4.5 & 3.4 & 9.9 & 7.8 & 3.5 \\
\hline & $1: 1: 2$ & 6.8 & 4.4 & 3.3 & 10.0 & 8.2 & 3.5 \\
\hline & $\begin{array}{l}\text { Mean of } \\
\text { median values }\end{array}$ & 7.6 & 4.8 & 3.9 & 10.8 & 8.4 & 3.9 \\
\hline & $\underline{-}$ & 0.6 & 0.4 & 0.7 & 1.0 & 0.6 & 0.4 \\
\hline & $s / \sqrt{n-1}$ & 0.3 & 0.2 & 0.4 & 0.6 & 0.4 & 0.2 \\
\hline$\dot{*}$ & $\begin{array}{l}\text { Median time to compl } \\
\text { No statistically signifi } \\
\text { ratios, therefore algal }\end{array}$ & $\begin{array}{l}\text { pment } \\
\text { ionship } \\
\text { tios ha }\end{array}$ & $\begin{array}{l}\text { rid der } \\
\text { e derno } \\
\text { ignor }\end{array}$ & $\begin{array}{l}\text { om dat } \\
\text { ompu bet }\end{array}$ & $\begin{array}{l}\text { days } f c \\
\text { of the }\end{array}$ & $\begin{array}{l}\text { elopme } \\
\text { n valu }\end{array}$ & algal species \\
\hline
\end{tabular}

England estuaries or ponds have values as high as $2.2 \times 10^{5}$ cells $\mathrm{ml}^{-1}$ been measured (Smayda, 1957; Hulburt, 1963). Yet the way larval development responds to temperature is apparently modified by the amount of food present.

One explanation of this paradox may lie in the ability of nauplii to harvest algal cells, i.e. the feeding efficiency of the larvae. At $30^{\circ} \mathrm{C}$ the concentration of food cells is seemingly irrelevant; larval survival and length of development were nearly the same at both $1 \times 10^{5}$ and $2 \times 10^{5}$ cells $\mathrm{ml}^{-1}$. At $20^{\circ} \mathrm{C}$, however, increasing the food concentration not only increased survival but also decreased the length of time for larval development to the cyprid stage. These results suggest that at $30^{\circ} \mathrm{C}$ a maximum feeding efficiency (intake per unit time) has already been reached and possibly surpassed at $1 \times 10^{5}$ cells $\mathrm{ml}^{-1}$, and that at $2 \times 10^{5}$ cells $\mathrm{ml}^{-1}$ there is a surplus of food which cannot be used. Apparently at lower temperatures increasing the food concentration can compensate for decreased feeding efficiency and result in an enhanced survival and a shorter time to complete development to the cyprid stage (Fig. 2). Barnes and Barnes (1958) anticipated such an hypothesis when they concluded that the availability of food may be fundamentally important in the development of planktonic larvae... [and] may interact with and compensate for temperature effects'.

The total length of planktonic life is determined not only by the 6 nauplius stages but also by the final nonfeeding cyprid which is only indirectly dependent upon the factors which control growth and survival of earlier instars. Lucas et al. (1979) have shown that the maximum time that a cyprid of Balanus balanoides can remain competent to settle - up to $5 \mathrm{wk}$ - is related to the amount of stored lipid energy-reserves. The amount of this reserve found in a cyprid will depend on conditions under which the naupliar stages grow. Tighe-Ford et al. (1970, p. 399) found that larvae of Elminius modestus, cultured under otherwise identical conditions, are smaller (shorter overall length) at the 6 th nauplius stage when grown at $20^{\circ}$ than at $10^{\circ} \mathrm{C}$. Can it be that at high temperatures the respiration and other catabolic activities increase at the expense of anabolic processes or 'scope for growth', and that increase in biomass is not closely coupled to morphological differentiation of nauplii larvae? Is it not possible that nauplii larvae grown at high temperatures will have less stored energy reserves?

Even though the maximum potential length of the planktonic cyprid stage is a function of food reserves, its actual length will be determined by the availability of a surface for attachment, and in Balanus balanoides, Elminius modestus and several other species of barnacles settlement is enhanced by an aggregation or intraspecific response of larvae to resident juveniles or adult members of its own species (Knight-Jones and Stephenson, 1950; Knight-Jones, 1953; Crisp, 1963). Accordingly, the length of the cyprid stage in $B$. balanoides will vary from a few days up to a maximum of $5 \mathrm{wk}$, depending both on an encounter with a site suitable for settlement and upon the amount of energy reserves

To summarize, we propose the hypothesis that both temperature and food concentration affect feeding efficiency and can modify the rate of development of the nauplius and the amount of food reserves found in the cyprid. To test this hypothesis will require research on the precise relationship of cell concentration and temperature to the feeding efficiency. The effect of high algal and larval concentrations presently used in 
laboratory experiments are unknown and the question of scaling may present some difficult future technical problems

Acknowledgements. We are grateful to Dr R. R. L. Guillard for providing us with stock cultures of unicellular algae and also for his freely given advice. Professor J. D. Costlow, Director of the Duke University Marine Laboratory, provided space during the early phases of the work. Dr. Peter Petraitis offered helpful suggestions and Amelie H. Scheltema critically read the text. The manuscript was much improved by the suggestions of 3 anonymous reviewers. Financial support was provided by contract N000 14-79-0-0071 NR 083-004 from the U.S. Office of Naval Research and by a grant from the National Science Foundation (EAR 79-26381).

\section{LITERATURE CITED}

Barnes, H., Barnes, M. (1958). The rate of development of Balanus balanoides L. larvae. Limnol. Oceanogr. 3: 29-32

Costlow, J. D., Bookhout, C. G. (1957). Larval development of Balanus eburneus in the laboratory. Biol. Bull. mar. biol. Lab., Woods Hole 112: 313-324

Crisp, D. J. (1963). Adsorbed layers: the stimulus to settlement in barnacles. Proc. R. Soc. Lond. B. 158: 364-387

Crisp, D. J., Ritz, D. A. (1967). Changes in temperature tolerance of Balanus balanoides during its life-cycle. Helgoländer wiss. Meeresunters. 15: 98-115

Davis, H. C., Guillard, R. R. (1958). Relative value of ten genera of micro-organisms as food for oyster and clam larvae. Fish. Bull. U. S. 58: 293-304

Fish, C. J. (1925). Seasonal distribution of the plankton the Woods Hole region. Bull. Bur. Fish, Wash. 41: 91-179

Freiberger, A., Cologer, C. P. (1966). Rearing acorn barnacle cyprids in the laboratory for marine fouling studies. J. Am. Soc, nav. Engrs, 78: 881-890
Henry, D. P., McLaughlin, P. A. (1975). The barnacles of the Balanus amphitrite complex (Cirripedia, Thoracica). Zool. Verh., Leiden 141: 3-254

Hirano, R. (1962). Mass rearing of barnacle larvae. Bull. mar Biol. Station Asamuchi, Tohoku Univ. 10: 77-80

Hulburt, E. M. (1963). The diversity of phytoplankton populations in oceanic, coastal, and estuarine regions. J. mar. Res. 21: 81-93

Knight-Jones, E. W. (1953). Laboratory experiments on gregariousness during settling in Balanus balanoides and other barnacles. J. exp. Biol. 30: 584-598

Knight-Jones, E. W., Stephenson, J. P. (1950). Gregariousness during settlement in the barnacle Elminius modestus Darwin. J. mar. biol. Ass. U. K. 29: 281-297

Landau, M., D'Agostino, A. (1977). Enhancement of laboratory cultures of the barnacle Balanus eburneus Gould using antibiotics. Crustaceana 33: 223-224

Landau, M., D'Agostino, A. (1978). Culture of the barnacle Balanus eburneus in artificial seawaters. Crustaceana 34 315-318

Lang, W. H. (1977). The barnacle larvae of North Inlet, South Carolina (Cirripedia: Thoracica). Ph. D. dissertation, University of South Carolina

Lucas, M. I., Walker, G., Holland, D. L., Crisp, D. J. (1979). An energy budget for the free-swimming and metamorphosing larvae of Balanus balanoides (Crustacea: Cirripedia). Mar. Biol. 55: 221-229

Moyse, J. (1963). A comparison of the value of various flagel lates and diatoms as food for barnacle larvae. J. Cons. perm. int. Explor, Mer 28: 175-187

Scheltema, R. S. (1967). The relationship of temperature to the larval development of Nassarius obsoletus (Gastropoda) Biol. Bull. mar. biol. Lab., Woods Hole 132: 253-265

Smayda, T. H. (1957). Phytoplankton studies in lower Narragansett Bay. Limnol. Oceanogr. 2: 342-359

Tighe-Ford, D. J., Power, M. J D., Vaile, D. C. (1970). Laboratory rearing of barnacle larvae for antifouling research. Helgoländer wiss. Meeresunters. 20: 393-405 